\title{
PERBANDINGAN KOMPONEN MINYAK ATSIRI ANTARA DAUN MUDA DAN DAUN DEWASA PADA HYPTIS SUAVEOLENS (L.)POIT.
}

\author{
Moralita Chatri $^{1 *}$, Mansyurdin ${ }^{2}$, Amri Bakhtiar $^{3}$, dan Perri Adnadi ${ }^{4}$ \\ Staf Pengajar Jurusan Biologi, FMIPA, Universitas Negeri Padang, Padang ${ }^{1 *}$ \\ Staf Pengajar Jurusan Biologi, FMIPA, Universitas Andalas, Padang ${ }^{2,4}$ \\ Staf Pengajar Fakultas Farmasi, Universitas Andalas Padang ${ }^{3}$ \\ moralitachatri@gmail.com, masyurdin@gmail.com,amri_bakhtiar@yahoo.com, \\ periadnadi@fmipa.unand.ac.id
}

\begin{abstract}
Hyptis suaveolens (L.) Poit is one of the species Lamiaceae family (Labiatae), is an aromatic plant and can produce essential oils. Essential oils of these plants can be utilized as antimicrobials. The chemical components contained in the essential oils in the same plant may vary as they are influenced by several factors, including the growth stage. Essential oils can be obtained by hydrodestilation and their components are analyzed using gas chromatography-mass spectrometry (GC-MS). The essential oil components are then compared between those found in young leaves and adult leaves. The results of analysis and identification showed that in young leaves there are 50 components while in adult leaves there are only 37 components. The main components of young leaves were $\beta$ caryophyllene $(34.65 \%)$, germacrene-D $(10.32 \%), \alpha$-bergamotene $(6.56 \%), \alpha$-copaene $(5.94 \%)$ and rimuene $(6.46 \%)$, Are $\beta$-caryophyllene $(23.53 \%)$, germacrene-D $(9.52 \%), \beta$ elemente $(6.53 \%)$ and rimuene $(13.19 \%)$. The components of $\alpha$-bergamotene and $\alpha$ copaene are not found in adult leaves.
\end{abstract}

Keywords :Hyptis suaveolens (L.) Poit, minyak atsiri, $\beta$-caryophyllene

\section{PENDAHULUAN}

Hyptis suaveolens (L.)Poit adalah salah satu jenis dari familia Lamiaceae (Labiatae),yang berasal dari Amerika Tropis, namun sekarang sudah tersebar luas di seluruh dunia (Barbosa et al., 2013).Di Indonesia dapat tumbuh dengan ketinggian $1.300 \mathrm{~m}$ di atas permukaan laut dan sering ditemukan pada lahan yang cukup mendapat cahaya matahari. Nama daerahnya adalah Ruku-ruku Utan, Sumengit (Sumbawa bagian Timur), Jukut Bau (Sunda), Basinan, Lampesan, Sangketan, Slangking (Jawa) dan di Madura disebut Komandhin (Heyne,
1987). Tumbuhan ini berupa herba, bercabang banyak, berbau keras, sering berkayu pada pangkalnya, tinggi $0,4-2 \mathrm{~m}$. batang berbulu, daun bulat telur dengan pangkal yang bentuk jantung membulat, bergerigi tak teratur (Henderson, 1959; Backer and Brink, 1965). Panjang daun umumnya $3-5 \mathrm{~cm}$ dan lebar 2-4 cm, permukaan daun mempunyai rambut kelenjer (Raizada, 2006; Steenis, 2006).Rambut kelenjer atau trikoma glandular dapat menghasilkan minyak atsiri yang aromatik (Simpson, 2006).Perhiasan bunga berupa kelopak (calyx) dengan panjang lebih kurang 5 
$\mathrm{mm}$ dan mahkota (corolla) yang berwarna biru, zigomorf dan bilabiate dengan panjang lebih kurang $8 \mathrm{~mm}$ (Raizada, 2006).Perkembangbiakan dapat terjadi secara vegetatif dan generatif (Aluri and Reddi, 1996).Di Indonesia, tumbuhan tersebut diangggap sebagai gulma dan tidak begitu dimanfaatkan.

Tumbuhan dari familia Labiatae banyak yang mempunyai trikoma glandularsebagai derivat dari jaringan epidermis dan merupakan struktur sekresi minyak atsiri.(Werker et al., 1993), salah satunya adalahHyptis suaveolens (L.) Berdasarkan hasil penelitian dari beberapa negara lain, minyak atsiri dari H.suaveolens (L.) Poit telah dimanfaatkan sebagai antimikroba, karena dapat menghambat aktifitas beberapa strain dari isolat bakteri dan jamur penyebab penyakit kulit pada manusia (Okonogi et al., 2005).).Minyak atsiri dari H.suaveolenjuga dapat menghambat pertumbuhan Saccharomyces cerevisiae, Fusarium moniliforme dan Mucor sp. (Malele,et al. 2003), Aspergillus plavus danA.ochraceus (Moreira,et.al. 2010 dan Sharma,et al. 2007), A.niger (Mandal,et al. 2007 dan Mbatchou, et al. 2010), A. parasiticus dan A. fumigatus (Moreira,et.al. 2010), Candida albicans, Cryptococcus dan Fusarium (Mbatchou, et al. 2010), Micrococcus luteus (Mandal, et al. 2007), Fusarium oxysporum f.sp. gladioli(Tripathi, et al. 2008). Selain itu juga dapat dimanfaatkan sebagai repellan dan insektisida terhadap Callosobruchus maculates, Rhyzopertha dominica, Sitophilus oryzae dan Tribolium castaneum (Tripathi and Upadhyay 2009) serta anti nyamuk Aedes aegipty, Anopheles stephensi dan Culex quinquefasciatus (Arivoli and Tennyson, 2011).
Minyak atsiri merupakan suatu hasil kegiatan seluler dari tumbuhan yang tergolong pada substansi nonprotoplasma bersifat cair dan biasanya terdapat dalam vakuola dari suatu struktur sekresi (Evert, 2006). Minyak atsiri (essential oil) juga disebut dengan minyak terbang (volatile oil) atau etheric oil (Koul et al., 2008; Can Baser and Demirci, 2007), dihasilkan oleh tumbuhan aromatik sebagai metabolit sekunder, beberapa minyak atsiri juga ditemukan pada hewan dan mikroorganisme (Bhargava et al., 2013). Minyak atsiri merupakan senyawa bahan alam, mudah menguap, dan sangat kompleks dan dicirikan dengan bau yang keras (Bakkaliet al., 2008). Sebagian besarbau minyakberasal dari campurandari komponen sehingga memberikanprofilbausecara keseluruhan, tetapi beberapaminyak atsiri baunyadidominasi olehkomponentunggal, seperticitral dalam minyaksereh (Hunter, 2009). Minyak tersebut mudah teroksidasi, larut dalam alkohol,kloroform, eter, aseton, karbon disulfide dan tidak larut dalam air (Bhargavaet al., 2013).Secara umum, minyak atsiri mempunyai bau yang enak, sehingga banyak digunakan dalam berbagai industri, terutama parfum (Chamorro et al., 2012).

Minyak atsiri merupakan campuran senyawa yang sangat heterogen (Zouari, 2013). Komponen minyak atsiri dapat mencapai 100 senyawa (Bohlmann and Keeling, 2008; Carson and Hammer, 2011), tetapi umumnya mengandung 2060 komponen pada konsentrasi yang berbeda (Bakkaliet al., 2008). Senyawa tersebut dicirikan dengan dua atau tiga komponen utama pada konsentrasi yang agak tinggi (20-70 \%) dibandingkan dengan komponen lainnya (Bakkali, 2008; Morcia, et al., 2013).Komponen 
tersebut berasal dari kelompok yang berbeda, kelompok terpen merupakan yang paling dominan.Diperkirakan lebih dari 1000 struktur monoterpen dan 3.000 struktur sesquiterpen yang terlibat dalam penyusunan minyak atsiri (Svoboda and Hampson, 1999), tetapi fenilpropanoid dan senyawa lainnya juga dapat ditemukan dalam persentase yang sedikit (Carson and Harmer, 2011). Secara garis besar, berdasarkan kuantitasnya, komponen minyak atsiri dapat dibagi atas tiga kelompok berdasarkan kuantitasnya, yaitu komponen utama (mayor), komponen minor dan komponen tambahan (Hunter, 2009).

Minyak atsiri disusun oleh komponen-komponen dari senyawa yang kompleks. Berdasarkan kualitasnya, komponen tersebut terbagi atas dua kelompok utama, yaitu senyawa terpen (dengan derivatnya) dan senyawa aromatik atau juga hidrokarbon dan senyawa teroksidasi. Terpen merupakan senyawa hidrokarbon yang terdiri dari molekul hidrogen dan karbon dengan rumus $\left(\mathrm{C}_{5} \mathrm{H}_{8}\right) \mathrm{n}$. Hidrokarbon ini dapat berbentuk asiklis, monosiklis, bisiklis atau trisiklis. Senyawa teroksidasi dapat berupa alkohol, aldehid, keton, fenol, oksida, lakton, eter dan ester (Svoboda and Hampson, 1999.

Pada jenis tumbuhan yang sama, komposisi dan komponen kimia minyak atsiri dapat bervariasi. Hal ini dapat dipengaruhi oleh beberapa faktor, baik dari luar maupun dari dalam tumbuhan itu sendiri (Zouari, 2013).Faktor tersebut antara lain adalah letak geografis alam, perbedaan musim,periode sebelum atau sesudah berbunga, waktu tanam atau waktu panen,tahap pertumbuhan (Viljoen et al., 2005, Marzouki et al., 2009, Arraiza et al., 2012, (Inan et al., 2011dan Nemeth, 2005). Selain itu, faktor-faktor lingkungan seperti cahaya, temperatur dan kelembaban juga dapat mengakibatkan perubahan biokimia dan perubahan fisiologis pada tumbuhan sehingga merobah kuantitas dan kualitas minyak atsiri (Gershenzon et al., 2000; Prins et al., 2010).

Tujuan penelitian ini adalah untuk mengetahui dan membandingkan komponen minyak atsiri yang terdapat pada daun muda dan daun dewasa dari H.suaveolens (L.)Poit.

\section{METODE PENELITIAN}

Penelitian dilakukan dari bulan Februari 2012 sampai bulan September 2013. di Laboratorium Teknologi Hasil Pertanian, Fakultas Teknologi Pertanian, Universitas Andalas Padang.

Bahan yang diambil adalah daun H.suaveolens (L.)Poit.yang masih dalam fase pertumbuhan vegetatif. Daun dibedakan antara daun muda dan daun dewasa. Daun muda merupakan daun yang masih dalam keadaan meristem dan belum sempurna perkembangannya, sedangkan daun dewasa merupakan daun yang telah sempurna perkembangannya. Daun-daun yang telah dipisahkan dihidrodestilasi dengan menggunakan Clevenger-type apparatus.

Analisis minyak atsiri dilakukan dengan menggunakan Gas Chromatography-Mass Spectroscopy (GS-MS ULTRA SHIMADZU) dengan kolom DB-5 MS, panjang $30 \mathrm{~m}$ dan diameter 0,25 mm. Kondisi kolom diatur dengan suhu awal $60 \mathrm{C}$, waktu awal 2 menit. Kenaikan suhu sebesar $3 \mathrm{C} /$ menit dan suhu akhir adalah 230 C. Sampel diinjeksikan sebanyak $(0,5 \mu l)$ dengan split ratio diatur menjadi $1: 20$. Jenis detector adalah MS dengan temperatur injector adalah 250 C. Gas pembawa Helium (He) dengan kecepatan aliran 125 


\section{Eksakta Vol. 18 No. 2 Oktober | 2017}

E-ISSN : 2549-7464, P-ISSN : 1411-3724

$\mathrm{ml} / \mathrm{menit}$ dan tekanan 230 $\mathrm{kPa}$.fragmentasi senyawanya. Identifikasi dilakukan berdasarkan Retensi Waktu/Retention Time (RT).Setiap puncak yang muncul dalam kromatogram memiliki waktu retensi yang berbeda. Identifikasi komponen minyak atsiri dilakukan dengan menggunakan Library: WILEY7 dan NIST27.

\section{.HASIL DAN PEMBAHASAN}

Minyak atsiri yang diperoleh dari
daun
H.suaveolens
(L.)Poit.dengan

metoda hidrodestilasi menggunakan Clevenger-type apparatus merupakan cairan yang berwarna kuning muda dengan bau yang agak menyengat. Untuk mengisolasi komponen minyak atsiri yang diperoleh dari daun muda dan daun dewasa.dilakukan dengan menggunakan GC-MS (Gas Chromatography-Mass Spectroscopy). Hasil identifikasi dapat dilihat pada Tabel 1 dan Gambar 2 serta spektrum GC-MS (Gambar 3 dan 4).

Table 1.Komponen Kimia dan Persentase Relatif Minyak Atsiri Daun Muda dan Daun Dewasa dari H. suaveolens(L.)Poit.

\section{$\%$ relatif}

\begin{tabular}{|c|c|c|}
\hline \multirow{2}{*}{ Komponen } & \multirow[b]{2}{*}{ Daun Muda } & \multirow[b]{2}{*}{ Daun Dewasa } \\
\hline & & \\
\hline$\alpha$-pinene & 0,12 & - \\
\hline Sabinene & 1,39 & - \\
\hline$\beta$-pinene & 0,31 & - \\
\hline$\alpha$-phellandrene & 0,87 & - \\
\hline Benzenacetaldehid & 0,06 & - \\
\hline$\alpha$-terpinene & 0,08 & - \\
\hline P-cymene & 0,15 & - \\
\hline 1,8 cineole & 4,02 & - \\
\hline D-limonen & 0,35 & - \\
\hline$\gamma$-terpineol & 0,24 & - \\
\hline Fenchone & 1,17 & 0,03 \\
\hline$\alpha$-terpinolene & 0,08 & - \\
\hline L-linalool & 0,07 & 0,17 \\
\hline Camphor & 0,05 & - \\
\hline Terpinen-4-ol & 0,98 & - \\
\hline$\alpha$-cubenene & 1,01 & - \\
\hline$\alpha$-copaene & 5,94 & - \\
\hline$\beta$-bourbonene & 0,90 & - \\
\hline$\beta$-cubenene & 0,47 & - \\
\hline$\beta$-elemene & 1,62 & 6,53 \\
\hline$\beta$-caryophyllene & 34,65 & 23,53 \\
\hline$\gamma$-cadinene & 0,21 & 3,84 \\
\hline$\alpha$-bergamotene & 6,56 & - \\
\hline$\alpha$-humulene & 2,28 & 0,44 \\
\hline
\end{tabular}




\section{Eksakta Vol. 18 No. 2 Oktober $\mid 2017$}

E-ISSN : 2549-7464, P-ISSN : 1411-3724

\begin{tabular}{|c|c|c|}
\hline alloaromadendrene & 1,03 & - \\
\hline$\beta$-farnesene & 0,16 & - \\
\hline Germacrene-D & $\mathbf{1 0 , 3 2}$ & $\mathbf{9 , 5 2}$ \\
\hline$\beta$-selinene & 1,57 & - \\
\hline Epi-bicyclosesquiphellandrene & 0,18 & - \\
\hline zingiberenol & 0,22 & - \\
\hline$\alpha$-selinene & 1,59 & - \\
\hline$\alpha$-muurolene & 0,20 & - \\
\hline Germacrene A & 1,06 & - \\
\hline Torreyol & 0,63 & - \\
\hline Cadinene & 1,23 & - \\
\hline Caryophyllene oxide & 0,65 & 4,19 \\
\hline Juniper camphor & 0,21 & 0,10 \\
\hline Calarene & 0,40 & - \\
\hline Globulol & 1,03 & 4,93 \\
\hline Bergamotol & 1,13 & - \\
\hline$\alpha$-phellandrene & 0,27 & 0,35 \\
\hline Benzene & 0,23 & - \\
\hline Rimuene & 6,46 & 13,19 \\
\hline phenanthrene & 0,74 & - \\
\hline Kaurene & 0,76 & 3,45 \\
\hline Thumbergol & 1,61 & - \\
\hline podocarpene & 0,08 & - \\
\hline Retinol accetate & 1,12 & - \\
\hline Cholest-14-en-3-ol & 4,10 & - \\
\hline 4-epidehydroabietol & 0,34 & - \\
\hline 3,5-dimethylethylbenzene & - & 1,01 \\
\hline Trans-linalooloxide & - & 0,03 \\
\hline Kamfanoon/Formosa camphor & - & 0,03 \\
\hline Borneol & - & 0,78 \\
\hline$\alpha$-citronellol & - & 0,10 \\
\hline Trans-geraniol & - & 0,24 \\
\hline 1,3 cyclopentadien & - & 0,09 \\
\hline 3-methoxy-4-aminoquinoline & - & 2,53 \\
\hline Calyculone E & - & 2,94 \\
\hline Aromadendrene oxide & - & 3,30 \\
\hline Z-valerenylacetate & - & 0,83 \\
\hline$\beta$-cendreoxide & - & 0,96 \\
\hline$\alpha$-santalol & - & 0,60 \\
\hline Hexamethyl-pyranoindane & - & 1,34 \\
\hline Hexanonitril & - & 0,24 \\
\hline menthadiene & - & 0,63 \\
\hline Pentadecansaeure & - & 1,28 \\
\hline abietatriene & - & 4,19 \\
\hline
\end{tabular}




\section{Eksakta Vol. 18 No. 2 Oktober 2017}

E-ISSN : 2549-7464, P-ISSN : 1411-3724

\begin{tabular}{|c|c|}
\hline $\begin{array}{l}\text { tricyclo[20.8.0.0E7,16]triacontan, } \\
1(22), 7(16) \text {-diepoxy }\end{array}$ & 1,80 \\
\hline Isochiapin B & 0,69 \\
\hline $\begin{array}{l}\text { 3,7,11,15-tetrameithyl-hexadeca- } \\
\text { 1,6,10,14-tetraen-3-ol }\end{array}$ & 0,81 \\
\hline Neophytadiene & 1,04 \\
\hline aristolenepoxide & 0,14 \\
\hline$\beta$ - ocimene & 1,11 \\
\hline Total & $100 \%$ \\
\hline $\begin{array}{l}\text { Pada Tabel1, terlihat pada daun } \\
\text { muda ditemukan } 50 \text { komponen, } \\
\text { sedangkan pada daun daun dewasa hanya } \\
37 \text { komponen. Komponen utama pada } \\
\text { daun muda adalah } \beta \text {-caryophyllene } \\
(34,65 \%) \text {, germacrene-D }(10,32 \%), \alpha- \\
\text { bergamotene }(6,56 \%), \quad \alpha \text {-copaene } \\
(5,94 \%), \beta \text {-elemene }(1,62 \%) \text {, rimuene } \\
(6,46 \%) \text {, sedangkan komponen utama } \\
\text { pada daun dewasa adalah } \beta \text {-caryophyllene } \\
(23,53 \%) \text { germacrene-D (9,52\%), } \beta- \\
\text { elemene }(6,53 \%) \text { dan rimuene }(13,13 \%) \text {. } \\
\text { Pada daun dewasa tidak ditemukan } \\
\text { komponen } \alpha \text {-bergamotene dan } \alpha \text {-copaene. } \\
\text { Komponen yang sama-sama } \\
\text { teridentifikasi pada daun muda dan pada } \\
\text { daun dewasa juga terlihat adanya } \\
\text { perbedaan komposisi. Seperti pada } \\
\text { komponen } \beta \text {-caryophyllene dan } \\
\text { germacrene-D yang mengalami } \\
\text { penurunan persentase relatif pada daun } \\
\text { dewasa. Pada daun muda, } \beta- \\
\text { caryophyllene teridentifikasi sebanyak } \\
34,65 \% \text {, sedangkan pada daun dewasa } \\
\text { hanya 23,53\%. Begitu juga dengan } \\
\text { germacrene-D, persentasenya lebih tinggi } \\
\text { pada daun muda (10,32\%) daripada daun } \\
\text { dewasa (9,52\%). Sebaliknya, persentase } \\
\beta \text {-elemene terjadi peningkatan dari daun } \\
\text { muda (1,62\%) ke daun dewasa (6,53\%), }\end{array}$ & 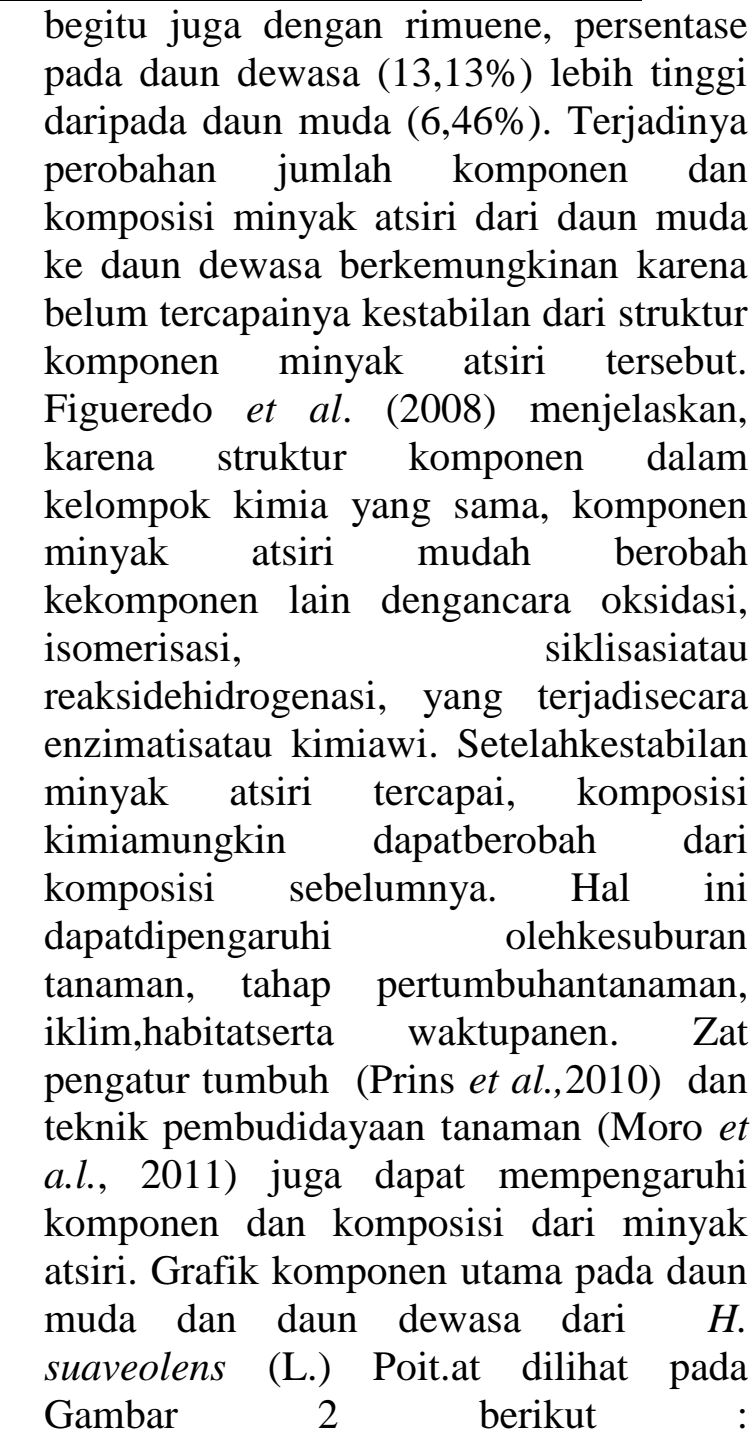 \\
\hline
\end{tabular}




\section{Eksakta Vol. 18 No. 2 Oktober $\mid 2017$}

E-ISSN : 2549-7464, P-ISSN : 1411-3724

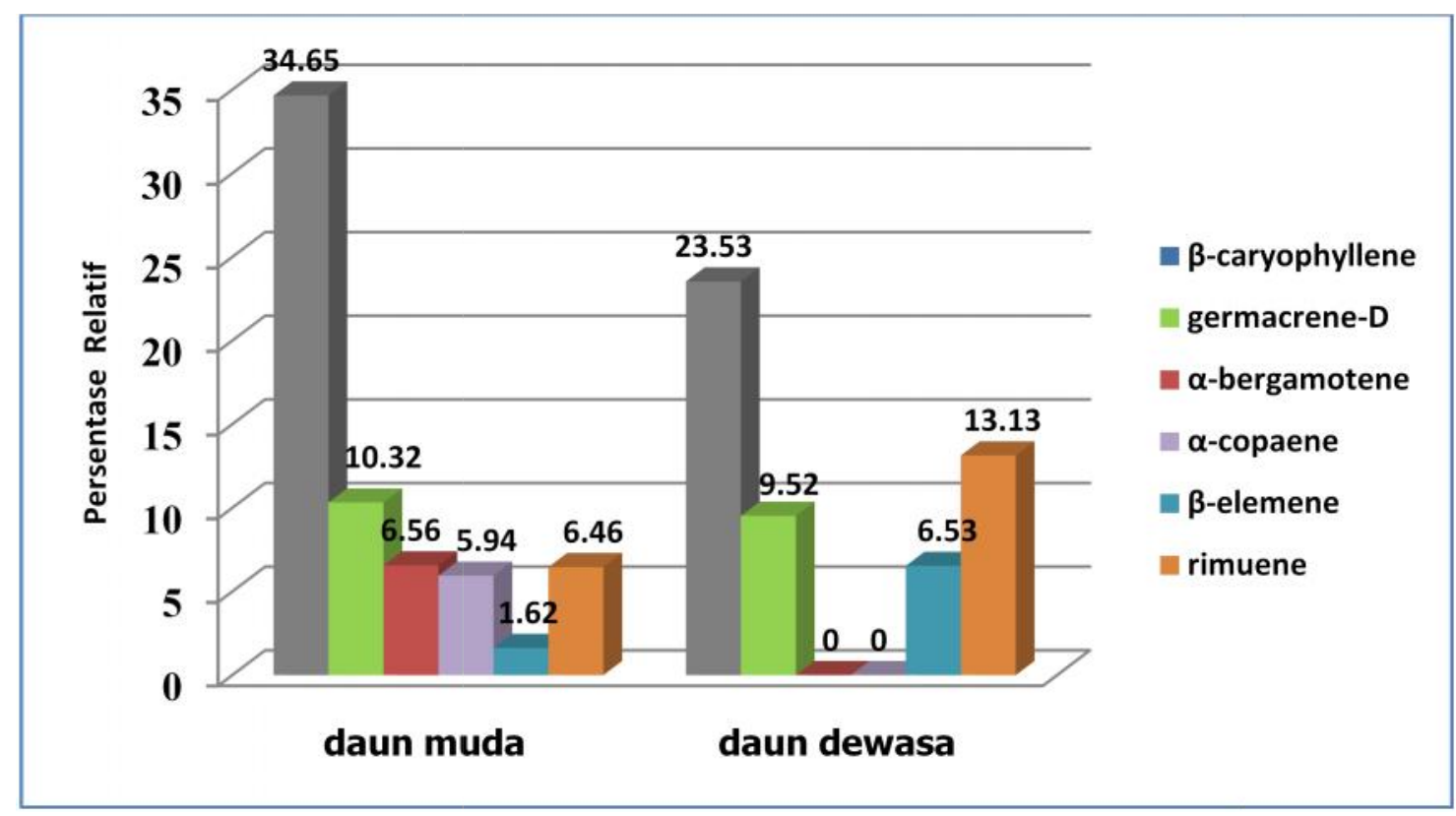

Gambar 2. Grafik komponen utama minyak atsiri H.suaveolens (L.) Poit.pada daun muda dan daun dewasa.

Perbedaan komposisi dari komponen minyak atsiri dapat terjadi pada tahap pertumbuhan yang berbeda walapun pada tumbuhan yang sama. Menurut Figueiredo et al.(2008), tahap perkembangan dari organ tumbuhan (daun, bunga dan buah) dapat menentukan komposisi dari minyak atsiri. Lacusic et al. ( 2013) melaporkan bahwa jumlah dan komposisi minyak atsiri Salvia officinalis tergantung berdasarkan perkembangan daun (daun muda dan daun dewasa). Pada daun muda, didapatkan persentase yang tinggi pada $\alpha$-humulene, viridifloroldanmanool, sedangkan pada camphor dan cis-thujone dengan persentase yang rendah. Selanjutnya pada pengamatan daun dewasa, persentase $\alpha$-humulene, viridifloroldanmanool secara signifikan menurun, sebaliknya persentase camphor dan cis-thujone menujukkan peningkatan.Hal yang sama terjadi pada minyak atsiri dari Ocimum sanctum (Dey and Choudhuri, 1983), persentase dari komponen utama minyak atsiri tumbuhan tersebut yaitu eugenol dan methyleugenol secara berangsur-angsur menurun tetapi caryophyllene meningkat terus sesuai dengan tahap perkembangan daun. Pada dua strain lemongrass (Cymbopogon), juga terjadi perobahan komposisi citral, geraniol dan geranyl acetate berdasarkan tahap perkembangan daun (Wen et al., 2012.

Hasil identifikasi komponen yang terdapat pada daun muda dan daun dewasa dengan menggunakan GC-MS dapat juga dilihat pada Gambar 3 dan 4. 


\section{Eksakta Vol. 18 No. 2 Oktober $\mid 2017$}

E-ISSN : 2549-7464, P-ISSN : 1411-3724

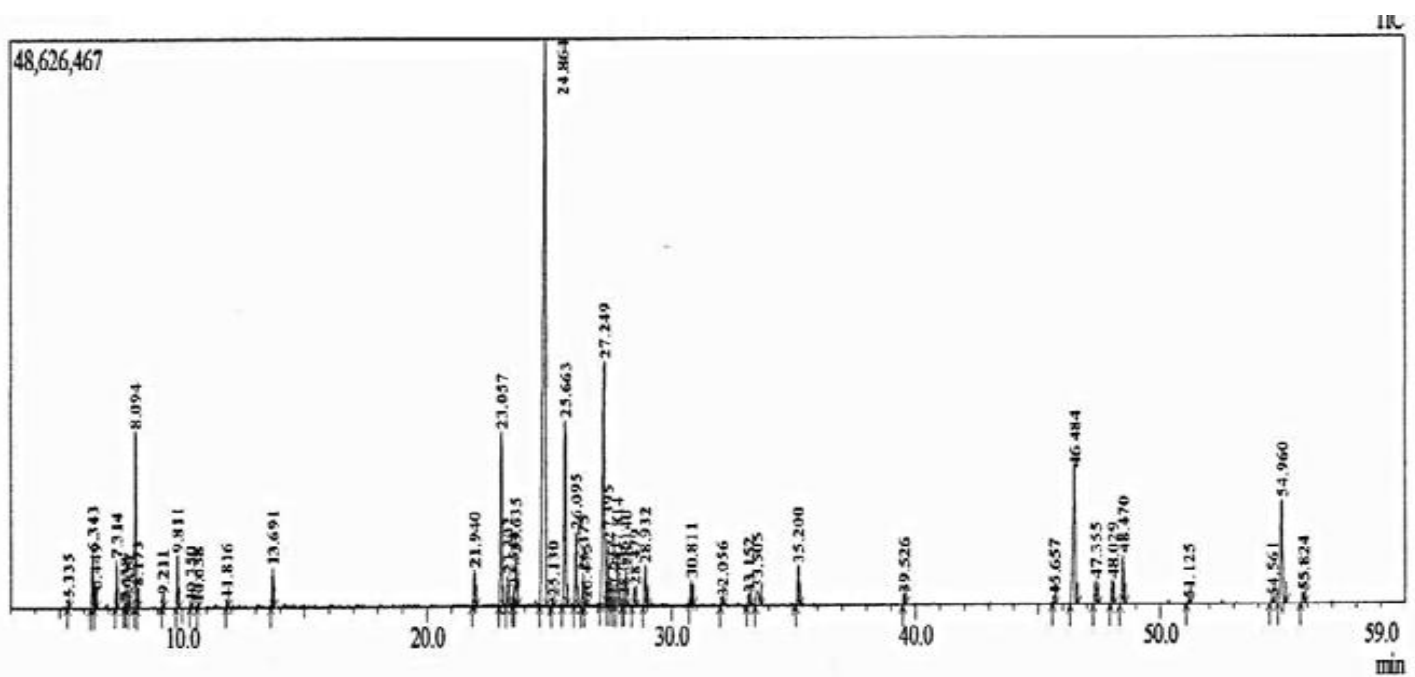

Gambar 2.Chromatogram Minyak Atsiri Daun Muda H. suaveolens (L.)Poit.

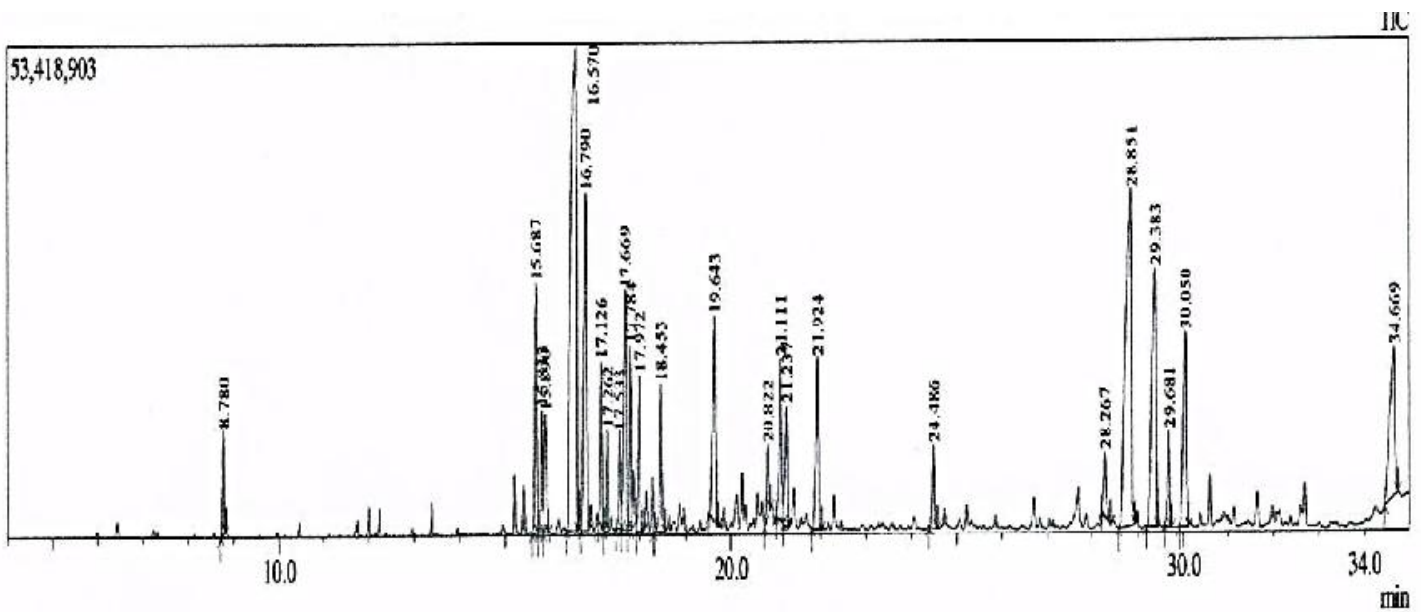

Gambar 3. . Chromatogram Minyak Atsiri Daun DewasaH. suaveolens (L.)Poit.

\section{KESIMPULAN}

Berdasarkan hasil analisis dan identifikasi komponen minyak atsiri pada daun muda dan daun dewasa dari $H$. suaveolens (L.) Poit, maka dapat diperoleh kesimpulan sebagai berikut :

1. Komponen kimia dari minyak atsiri $H$. suaveolens (L.) Poit pada daun muda lebih banyak daripada daun dewasa. Pada daun muda terdapat 50 komponen, sedangkan daun dewasa hanya terdapat 37 komponen.

2. Komponen utama pada daun muda adalah $\beta$-caryophyllene $(34,65 \%)$,
germacrene-D $(10,32 \%), \quad \alpha-$ bergamotene $(6,56 \%)$, rimuene $(6,46 \%)$, dan $\alpha$-copaene $(5,94 \%)$, sedangkan komponen utama pada daun dewasa adalah $\beta$-caryophyllene $(23,53 \%)$, germacrene-D $(9,52 \%), \quad \beta$ elemene $(6,53 \%)$ dan rimuene $(13,13)$.

\section{DAFTAR PUSTAKA}

Arraiza M P., C Arrabal and J V Lopez. 2012. Seasonal variation of essential oil yield and composition 
sage (Salvia officinalis L.) grown in Castilla - La Mancha (Central Spain).

Arivoli S and S Tennyson.2011. Mosquitocidal Activity of Hyptis suaveolens (L.) Pot (Lamiaceae) Extracts against Aedes aegypti, Anopheles stephensi and Culex quinquefasciatus

(Diptera:Culicidae). International Journal of Recent Scientific Research. 2 (5): 143-149.

Backer, C.A and R.C.B Van de Brink. 1965. Flora of Java. Vol. II. N.V.P Noordhoff-Graningen. Netherlands.

Bakkali, F., S.Averbeck, D Averbeck and M Idaomar. 2008. Biological Effects of Essential Oil- A review. Food Chem Toxicol 46 (2); 44675.

Barbosa, L.C.A., F.T Martins, R.R Teixera, M Polo and R.M Montanari. 2013. Chemical Variability and Biological Activities of Volatile Oils from Hyptis suaveolens (L.) Poit (Review Article).Agriculturae Conspectus Scientifus. Vol. 78, No.1: 1-10.

Baser, K H C and F Demirci. 2007. Chemistry of Essential Oils in Flavours and Fragrances, Chemistry, Bioprocessing and Sustainability.R. G. Berger (Ed.). Springer.Berlin Heidelberg New York.

Bhargava, V.V., S C Patel and K.D Desai. 2013. Importance of terpenoid and essential oils in chemotaxonomic approach. International Journal of Herbal Medicine, Vol. 1 (2), 14-21.

Bohlmann, J. and C.I Keeling. 2008. Terpenoid Biomaterial (Harnessing Plant Biomass for Biofuels and Biomaterial).The Plant Journal 54: 656-669.

Carson, C.F and K A Hammer. 2011. Chemistry and Bioactivity of Essential Oils in Lipids and Essential Oils as Antimicrobial Agents (Thormar H., Eds). John Wiley \& Sons.Ltd. New Delhi.

Chamorro, E.R., S.N Zambon and W.G Morales. 2012. Study of chemical composition of essential oils by gas chromatography (Gas Chromatography in Plants Science, Wine Technology, Toxicology and Some Specific Application). (Salih B and O. Celikbicak, Eds.)In Tech, 358 pp.

Dey and Choudhuri. 1983. Effect of leaf development stage on change in essential oil of Ocimum sanctum L. Biochem.Physiol.Pflanzen 178, 331-336.

Evert, R.F . 2006. Esau's Plant Anatomy. Meristems, Cells and Tissue of the Plant Body : their Structure, Function and Development. 3nd.ed.John Wiley \& Sons, Inc. New Jersay : 447-472.

Figueiredo, A C, J G Barroso, L G Pedro and J J C Scheffer. 2008. Factor affecting secondary metabolite production in plants: volatile components and essential oils. 
Flavour and Fragrance Journal, 23, 213-226.

Gershenzon, J., M.E McConkey and R.B Croteau. 2000. Regulation of monoterpenes accumulation in leaves of peppermint. Plant Physiol 122: 205-213.

Hunter,M. 2009. Essential Oils; Agriculture, Science, Industry and Entrepreneurship (A Focus on The Asia-Pasifik Region). Nova Science Publishers, Inc. New York. 773 pp.

Henderson.1959. Malayan Wild Flowers (Dicotyledons). Tien Wah Press ltd., Singapore

Heyne, K. 1987. Tumbuhan Berguna Indonesia.Jilid 3.Badan Penelitian dan Pengembangan kehutanan. Departemen Kehutanan. Jakarta.pp 1698.

Mbatchou V.C., S Abdullatif and R Glover. 2010. Phytochemical Screning of Solfent Extracts from Hyptis suaveolens LAM for Fungal Growth Inhibitation. Pakistan Journal of Nutrition 9 (4): 358-361.

Inan, M., M. Kirpik, D.A Kaya and S. Kirici. 2011. Effect of harvest time on essential oil composition of Thymbra spicata L. growing in flora of Adiyaman. Advance in Environmental Biology, 5 (2): 356-358.

Koul, O., S. Walia and G.S Dhaliwal. 2008. Essential oils as pesticides:
Potential and Constraints. Biopestic. Int. 4(1): 63-84.

Lacusic B S., M S Ristic, V N Slavkkovskka, D L Stojanovic and D V Lakusic. 2013. Variation in essential oil yields and compositition of Salvia officinalis (Lamiaceae) at different developmental stage. Botanica Serbic,37 (2): 127-139.

Malele, R.S., C.K Mutayabarya, J.W Mwangi, G.N Thoithi, A.G Lopez, F.I Lucini and J.A Zigadlo.2003. Essential Oil of Hyptis suaveolens (L.)Poit. From Tanzania: Composition and Antifungal Actifity. Journal of Essential Oil Research 15:438-440.

Mandal, S.M., K.C Mondal, S.Dey and B.R Pati. 2007. Antimicrobial Activity of The Leaf Extracts of Hyptis suaveolens (L.) Poit.Short Communication. 69 (4): 568-569.

Marzouki H., A Elaissi, A Khaldi, D Falconieri, B Marongiu, A Piras and S Porcedda. 2009. Seasonal and geographical variation of Laurus nobilis L. essential oil from Tunisia. The Open Natural Products Journal, 2: 86-91.

Morcia, C., G.Tumino and V. Terzi. 2013. Plant Bioactive Metabolites for Cereal Protection Againts Fungal Pathogens. In Antifungal Metabolites from Plants (M.Razzaghi-Abyaneh and M.Rai, Eds.). Springer Heidelberg, New York. 
Moreira, A.C.P., E de Oliveira Lima., P.A Wanderley., E.S Carmo and E.L de Souza.2010. Chemical Composition and Antifungal Activity of Hyptis suaveolens(L.)Poit Leaves Essential Oil Againts Aspergillus Species. Brazilian Journal of Microbiology 41:28-33.

Moro, A., A. Zalacain, J.H Mendoza and M Carmona. 2011. Effects od agronomic practices on volatile composition of Hyssopus officinalis L. essential oils. Molecules, 16: 4131-4139.

Nemeth, E. 2005. Changes in Essential Oil Quantity and Quality Influenced by Ontogenetic Factors.Proc. WOCMAP III, Vol. 1: Bioprospecting \& Ethnopharmacology. Eds. J. Bernath, Nemeth, L.E. Craker and Z.E.Gardner. Acta Hort 675, ISHS: 159-165.

Okonogi, S., S. Chansakaow, S. Vejabhikul, P. Tharavichitkul, J. Lerphokanont, A. Nakano and F. Ikegami. 2005. Antimicrobial activity and pharmaceutical development of essential oil from Hyptis suaveolens. Proc. WOCMAP III. Vol. 4; Targeted Screening of MAPs, Economics \& Law Eds. C. Franz, A. Mathe, L.E Craker and Z.E Gardner. Acta Hort.678, ISHS : 163-169.

Prins, C.L., I.J.V Vieira, S P Freitas. 2010. Growth regulators and essential oil production. Braz.J.Plant Physiol., 22(2): 91102.
Raizada, P. 2006. Ecological and vegetative characteristics of a potent invader, Hyptis suaveolens Poit.from India. Lyonia (A Journal of Ecology and Application). Vol. 11 (2): 115-120.

Sharma N., U.K Verma and A..Tripathi. 2007. Bioactivity of Essential Oil from Hyptis suaveolens against Storage Mycoflora.Donahaye E.J., Navarro S., Bell C., Jayas D., Noyes R., Phillips T.W (Eds.). Proc.Int.Conf.Controlled Atmosphere and Fumigation in Stored Product, Gold-Coast Australia. 8-13 ${ }^{\text {th }}$ August 2004. FTIC Ltd.Publishing, Israel.pp. 99-116.

Steenis, 2006.Flora untuk Sekolah di Indonesia.PT Pradya Paramita. Jakarta.

Svoboda, K. P and J. B Hampson,. 1999, Bioactivity of essential oils of selected temperature aromatic plants: antibacterial, antioxidant, anti-inflammatory and other related pharmacological activities. Procceedings NAHA, 25-28 september, St. Louis Missouri, USA: 105-127.

Tripathi, P., N.K Dubey and A.K Shukla. 2008. Use of some essential oils as post-harvest botanical fungisides in the management of grey mould of grapes caused by Botrytis cinerea. World $\mathbf{J}$ Microbiol Biotechnol, 24: 39-46.

Tripathi, A.K and S. Upadhyay. 2009. Repellent and Insectisidal Activities of Hyptis suaveolen 


\section{Eksakta Vol. 18 No. 2 Oktober | 2017}

E-ISSN : 2549-7464, P-ISSN : 1411-3724

(Lamiaceae) Leaf Essential Oil Against Four Stored-Grain Coleopteran Pest. International Journal of Tripical Insect Science.29:219-228.

Viljoen, A.M., S. Subramoney, S.F van Vuuren, K.H.C Baser and B. Demirci. 2005. The composition, geographical variation and antimicrobial activity of Lippia javanica (Verbenaceae) leaf essential oils. Journal of Ethnopharmacology, 96 : 271277.

Wen, H.I., N. Aoki and R. Ohsugi. 2012. Variation in essential oil content and composition during leaf development and growth of lemongrass. Trop.Agr. Develop. 56(1) : 14-24.

Werker E., E Putievsky, U Ravid, N Duda and I Katziri.1993.Glandular Hairs and Essential Oil in Developing Leaves of Ocimum basilicum L. (Lamiaceae).Annals of Botany 71: 43-50.

Zouari, N .2013 Essential Oils Chemotypes: A Less Known Side. Med. Aromat.Plants , Vol. 2 (2). e145. doi:10.4172/2167$0412.1000 \mathrm{e} 145$. 